\title{
Research Paper Economics of production and marketing of tomato in Amravati district
}

See end of the paper for authors' affiliations

Correspondence to :

\section{R.M. JORWAR}

Shri Shivaji Agriculture

College, AMRAVATI (M.S.)

INDIA

Email : ramharijorwar450

@ gmail.com

\section{Paper History :}

Received : 27.09 .2016

Revised : 15.01.2017;

Accepted : 25.01.2017
ABSTRACT : In this study an attempt has been made to study the "Economics of tomato production in Amravati district" with view to work out the economics tomato production. The economic analysis of data indicating that cost ' $C$ ' was found to Rs. 136110.00 , Rs. 142778.00 and Rs. 148614.00 per hectare for small, medium and large growers, respectively. Net returns over cost ' $\mathrm{C}$ ' was Rs. 6300.52, Rs. 14110.80 and Rs. 24202.70 per hectare and input-Output ratio at cost ' $\mathrm{C}$ ' was $1.05,1.10$ and 1.16 for small, medium and large growers, respectively.

KEY Words : Tomato, Cost of cultivation, Cost of production

How To Cite This Paper : Jorwar, R.M., Ulemale, D.H. and Sarap, S.M. (2017). Economics of production and marketing of tomato in Amravati district. Internat. Res. J. Agric. Eco. \& Stat., 8 (1) : 56-59, DOI : 10.15740/HAS/ IRJAES/8.1/56-59. 